\title{
Antipyretic effect of ethanol extract of plant leaves of garden croton (Codiaeum variegatum) in male mice
}

\author{
Mohammad Kanedi 1, ${ }^{*}$, Wawan Abdullah Setiawan ${ }^{1}$, Kusuma Handayani ${ }^{1}$, Nopiansyah ${ }^{2}$ and Vivi Febriyanti ${ }^{2}$ \\ ${ }^{1}$ Department of Biology, Faculty of Math and Sciences, University of Lampung, Bandar Lampung, Indonesia. \\ ${ }^{2}$ Department of Pharmacy, Faculty of Math and Sciences, Tulangbawang University, Bandar Lampung, Indonesia.
}

GSC Biological and Pharmaceutical Sciences, 2021, 14(03), 202-206

Publication history: Received on 17 February 2021; revised on 21 March 2021; accepted on 23 March 2021

Article DOI: https://doi.org/10.30574/gscbps.2021.14.3.0087

\begin{abstract}
Codiaeum variegatum (L.) is known to contain bioactive compounds that have many pharmacological properties such as abortifacient, antiamoebic, antibacterial, anticancer, antifungal, and antioxidant. This study aims to reveal whether the ethanol fraction of leaf extract of this plant has antipyretic activity. The male mice $(n=25)$ with a weigh range of 20 $-30 \mathrm{~g}$ were divided into five groups (5 mice each). To make pyrexia condition, the animals were induced with DPT-HBHIB vaccine. The ingredients given to the animals were as follows: distilled water as the negative control; standard drug (paracetamol) as positive control; and three different dosage of croton leaves extract namely: 71.5, 143 and $286 \mathrm{mg} / \mathrm{kg}$ BW. The body temperature of the mice was measured using a digital thermometer through the rectal opening every 30 minutes for 180 minutes. The results showed that ethanol fraction of croton plant leaf extract at the dosage of 143 and $286 \mathrm{mg} / \mathrm{kg}$ BW statistically have the same effect as paracetamol in decreasing body temperature of mice. Therefore, it can be concluded that plant extract of garden croton is potential to be used as antipyretic remedy.
\end{abstract}

Keywords: Codiaeum variegatum; Garden croton; Antipyretic drug; Puring

\section{Introduction}

Codiaeum variegatum (L.), the croton plants, is an evergreen shrub that usually grown as an ornamental in the backyard or gardens in many tropical countries such as Philippine, Malaysia, New Guinea, including Indonesia. In these countries, the plant that called 'puring' in Indonesia has long been used as traditional medicine to treat diarrhea, to stimulate menstruation, or to facilitate parturition. Pharmacological researches on the efficacy of croton plants showed that the extract of this plant have the following properties: abortifacient, antiamoebic, antibacterial, anticancer, antifungal, and antioxidant [1].

Other bioactivity test showed that the extract of the croton plant had antilithiatic activity [2]. Bioassay against fish showed that at sub-lethal concentrations, this plant extract decrease haematological parameters and increased mortality [3]. On Culex mosquito larvae, bioassay showed that Cordiaeum variegatum extract has larvicidal properties [4].Phytochemical studies revealed that the plant leaf extract of croton contained glycosides, tannins, alkaloids, flavonoids, steroids, saponins, and triterpenoids [5]. Such bioactive substances are known to have antipyretic properties. Asparagus racemosus and Bombax malabaricum are examples of plants that contain phytochemicals similar to Cordiaeum variegatum. Both plant extract of Asparagus racemosus and Bombax malabaricum are revealed to show antipyretic properties in an in-vivo test $[6,7]$.

\footnotetext{
* Corresponding author: Mohammad Kanedi

Department of Biology, Faculty of Math and Sciences, University of Lampung, Bandar Lampung, Indonesia. 
Because the Codiaeum variegatum is rich in phytochemicals that have the potential to be antipyretic, it is reasonable to suspect that the croton plant has antipyretic properties.In an effort to test this hypothesis, a test for the antipyretic effect of ethanol extract of puring leaves has been carried out in mice induced with DPT vaccine.

\section{Material and methods}

\subsection{Plant materials and extraction}

The fresh plant leaves of garden croton Codiaeum variegatum (L.) Rumph. ex A. Juss were collected from the village of Karyatani, Central Lampung Regency, Lampung Province, Indonesia. Taxonomic determination of the plant was carried out by plant taxonomist at the Botanical Laboratory, Department of Biology, Faculty of Mathematics and Natural Sciences, University of Lampung, Indonesia. The fresh samples of the plant leaves were washed and rinsed using running tap water and air dried. The leaves were chopped into small pieces and then sun-dried under a black cloth cover in order to prevent the sample from being exposed to UV rays. The dried chopped leaves (200 g) are macerated using $70 \%$ ethanol in a dark glass container. The filtrate were collected by filtration after 24 hours, while the solid residues were re-macerated using the same solvent every 24 hours until the extract is completely clear. The filtrate is then evaporated using a rotary evaporator to obtain a thick extract of croton leaves. To make the ethanol fractions of the extract, liquid-liquid fractionation were performed. Into $50 \mathrm{~g}$ of the paste was added $50 \mathrm{ml}$ ethanol and $100 \mathrm{ml}$ of $\mathrm{n}$ hexane in a separating funnel. Into the ethanol fraction were then added $100 \mathrm{ml}$ chloroform. The residual ethanol fraction obtained were evaporated at $60^{\circ} \mathrm{C}$ and dried in an oven at $60^{\circ} \mathrm{C}$. The dried extract of the croton leaves was then suspended in distilled water containing $0.5 \% \mathrm{CMC}(\mathrm{w} / \mathrm{v})$.

\subsection{Preparation of the test ingredient}

The homogenous suspension of plant leaves extract of croton transferred into measuring flask and serially diluted to with distilled water according to the desired dosage levels. There were five different test ingredients prepared in this experiment, namely: distilled water as the negative control; standard drug (Paracetamol) as positive control; and three different dosage of croton leaves extract namely: 71.5, 143 and $286 \mathrm{mg} / \mathrm{kg} \mathrm{BW.}$

\subsection{Animals and experimental design}

Male mice used in this study $(n=25)$ with a weigh range of 20 - 30 g were obtained from Veterinary Centre Lampung, Indonesia. Before experiment, the animals were allowed to acclimate for 1 week, fed with standard diet and water ad libitum and housed in a $12 \mathrm{~h}$ light/dark cycle at $25 \pm 2{ }^{\circ} \mathrm{C}$. This study was conducted according to guidelines issued by Institutional Research Ethics Committee of the Faculty of Mathematics and Sciences, University of Lampung, Indonesia. By applying a completely randomized design the test mice were divided into five experimental groups (5 mice each) according to the five ingredients prepared.

\subsection{The test protocol}

To determine the effect of treatment on changes in body temperature of mice, after the initial temperature (baseline) was known, each mouse was injected with DPT-HB-HIB vaccine at the dose of $0.05 \mathrm{~mL} / 20 \mathrm{~g}$ BW. One hour later all mice were treated with the ingredient prepared for each treatment group. The body temperature of the mice was then measuredusing a digital thermometer through the rectal opening every 30 minutes for 180 minutes.

\subsection{Statistical analysis}

One way ANOVA was applied in the data analysis and the LSD was used in the post hoc test.

\section{Results and discussion}

The mean values of mice rectal temperature before and in 10 minutes after injected with vaccine and the results of temperature measurement conducted every 30 minutes for 180 minutes are presented in Table 1 . The pattern of temperature changes in the rectum of mice after giving the extract is presented in Figure 1. The post hoc test using LSDtest against the mean values of rectal temperature at the end of experiment is shown in Table 2. 
Table 1 Rectal temperature of mice before and after vaccine injection.

\begin{tabular}{|l|l|l|l|l|l|l|l|l|}
\hline \multirow{2}{*}{ Treatment } & \multicolumn{6}{|c|}{ Mean values of rectal temperature of mice at the $i^{\text {th }}$ minute } \\
\cline { 2 - 10 } & $\mathrm{T}_{0}$ & $\mathrm{~T}_{\mathrm{i}}$ & 30 & 60 & 90 & 120 & 150 & 180 \\
\hline $\mathrm{H}_{2} \mathrm{O}$ (-Control) & 35.9 & 37.98 & 38.22 & 38.44 & 38.62 & 38.78 & 38.92 & 38.82 \\
\hline Paracetamol (+ Control) & 35.86 & 38.04 & 38.3 & 36.14 & 36.0 & 35.84 & 35.62 & 35.4 \\
\hline Extract $71.5 \mathrm{mg} / \mathrm{kg} \mathrm{BW}$ & 35.78 & 37.84 & 38.2 & 38.64 & 38.36 & 38.12 & 37.9 & 37.7 \\
\hline Extract $143 \mathrm{mg} / \mathrm{kg} \mathrm{BW}$ & 35.7 & 37.84 & 38.12 & 38.5 & 37.92 & 37.5 & 36.82 & 36.26 \\
\hline Extract $286 \mathrm{mg} / \mathrm{kg} \mathrm{BW}$ & 35.74 & 37.9 & 38.24 & 38.46 & 36.5 & 36.18 & 36.02 & 35.76 \\
\hline
\end{tabular}

To: Baseline temperature Ti: Rectal temperature 1 hour after vaccine injected

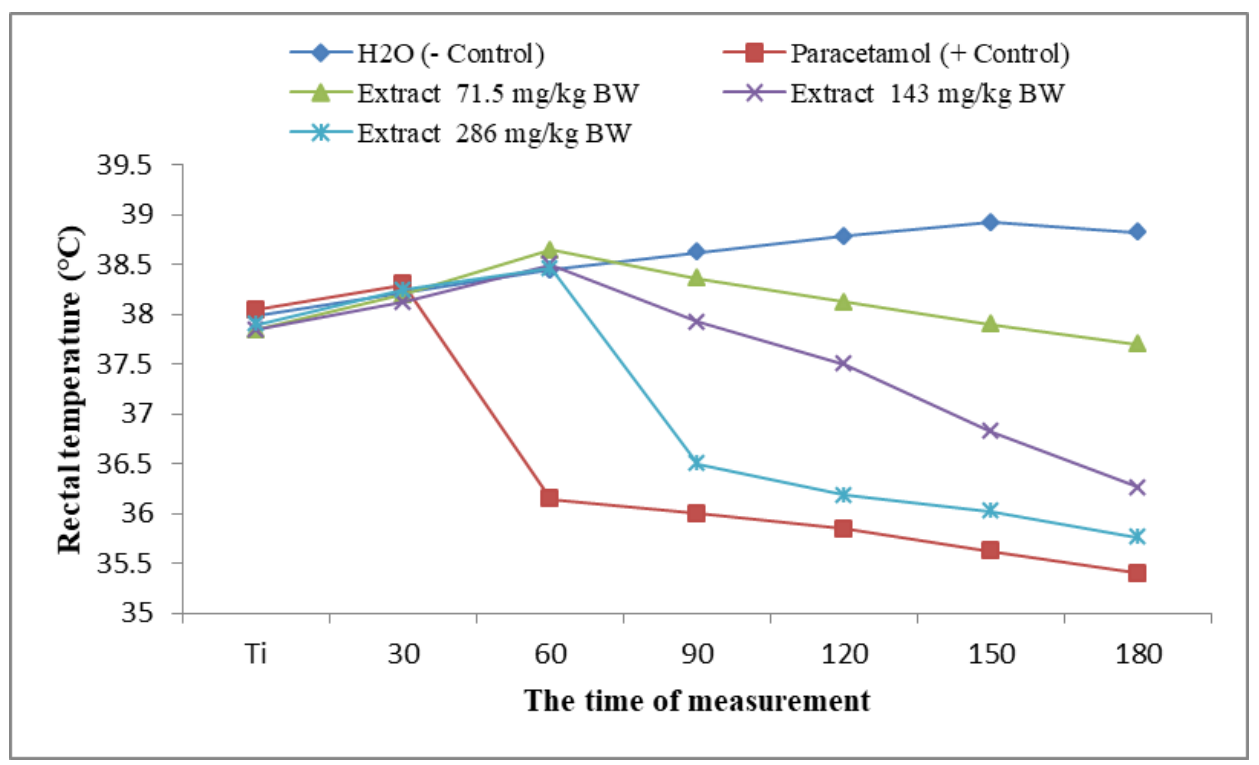

Figure 1The pattern of temperature changes of the rectum of mice after giving the extract. T1 is the rectal temperature of mice one hour after the animals injected with vaccine when the treatment given.

Table 2 Results of LSD test on the mean values of mice rectal temperature at the end of experiment (180 minutes).

\begin{tabular}{|l|l|}
\hline Treatment & Rectal temperature $\left({ }^{\circ} \mathrm{C}\right)$ \\
\hline H2O (-Control) & $38.82^{\mathrm{a}}$ \\
\hline Paracetamol (+ Control) & $35.4^{\mathrm{c}}$ \\
\hline Extract $71.5 \mathrm{mg} / \mathrm{kg} \mathrm{BW}$ & $37.7^{\mathrm{a}}$ \\
\hline Extract $143 \mathrm{mg} / \mathrm{kg} \mathrm{BW}$ & $36.26^{\mathrm{bc}}$ \\
\hline Extract $286 \mathrm{mg} / \mathrm{kg} \mathrm{BW}$ & $35.76^{\mathrm{bc}}$ \\
\hline
\end{tabular}

Based on the data presented in Table 1, Figure 1, and Table 2, the research hypothesis of this experiment has been is answered, that the leaf extract of the croton plant has antipyretic properties. The ability of the ethanol fraction of puring leaf extract in reducing fever in mice induced by DPT-HB-HIB vaccine for three hours (180 minutes) was not significantly different from the standard drug Paracetamol. This finding is similar to the findings of other studies 
regarding the antipyretic effect of phytochemicals from various plant species. Almost all types of plants that have feverreducing properties contain similar bioactive substances to that of croton plant extracts. As revealed in a phytochemical screening report, Codiaeum variegatum (L.) is rich in alkaloids flavonoids, saponins, phenolics, tannins and terpenoids [8].

Heliotropium indicum is one example of plant that showed antipyretic property in albino rat induced by Brewer's yeast and using paracetamol as the positive control. Leaf extract of this plant known to contain alkaloids, glycoside, phytosterol, flavonoidsand saponins [9]. Other examples of plant extract that effective in reducing pyrexia are Saraca asoca Roxb, Curcuma zedoaria Rosc and Ximenia americana. Seeds extract of Saraca asoca was revealed to contain saponin, tannins and flavonoids [10]. Phytochemical screening of ethanol extract of Curcuma zedoaria showed presence of tannins, flavonoids, saponins, alkaloids, terpenoids and steroids [11]. Lastly, leaf extract of Ximenia americana was known to contain alkaloids, flavonoids, saponins, phenolics and terpenoids [12].

The standard drug used as a comparison in this study was paracetamol.There are several ways of paracetamol in reducing pyrexia, by reducing levels of prostaglandins acting on cyclooxygenase enzymes, enhancing antipyretic message within brain and stimulating anti-inflammatory signals at injury site [13]. Among the active ingredients contained in croton leaf extract that should be suspected of having a similar mechanism of action to parcetamol in reducing body temperature are flavonoids. The flavonoidal compounds are known as the predominant inhibitors of cyclooxygenase and lipoxygenase [14]. Inhibition on these two enzymes is an important part of inhibit proinflammatory mediators, the prostaglandins [15].

\section{Conclusion}

At the dosage of 143 and $286 \mathrm{mg} / \mathrm{kg}$ BW the ethanol fraction of leaf extract of Codiaeum variegatum showed activity similar to that of standard drug, paracetamol, in reducing rectal temperature in vaccine-induced pyrexia mice. So that it can be concluded that plant leaf extract of croton plant is potential to be used as antipyretic agent.

\section{Compliance with ethical standards}

\section{Acknowledgments}

We thank to laboratory technician at the Department of Pharmacy Tulangbawang University and Department of Biology, Faculty of Math and Sciences, University of Lampung for their supports.

\section{Disclosure of conflict of interest}

The authors declare that there is no conflict of interest.

\section{Statement of ethical approval}

The research ethics is approved by Institutional Research Ethics Committee of the Faculty of Mathematics and Sciences, University of Lampung, Indonesia.

\section{References}

[1] Salatino A., Salatino MLF, Negri G. Traditional uses, chemistry and pharmacology of Croton species (Euphorbiaceae). J. Braz. Chem. Soc. 2007; 18 (1): 11-33

[2] Jha U, Singh A, Oswal RJ. In-Vitro Antilithiatic Effect of Ethanolic Extract of Codiaeum Variegatum (L.) Blume, Asian Journal of Pharmaceutical Technology \& Innovation. 2016; 04 (17): 95-102.

[3] Shahi J,Singh A. Effect of bioactive compounds extracted from euphorbious plants on hematological and biochemical parameters of Channa punctatus. Rev. Inst. Med. Trop. Sao Paulo. 2011; 53(5): 259-63.

[4] Awosolu 0, Adesina F, Iweagu M. Larvicidal effects of croton (Codiaeum variegatum) and Neem (Azadirachta indica) aqueous extract against Culex mosquito. International Journal of Mosquito Research. 2018; 5(2): 15-18.

[5] Anim MT, Larbie C, Opong RA, Tuffour I, Owusu KBA, Aning A. Extracts of Codiaeum variegatum (L.) A. Juss is Cytotoxic on Human Leukemic, Breast and Prostate Cancer Cell Lines. J App Pharm Sci, 2016; 6 (11): $087-093$. 
[6] Vasundra Devi PA, Divya Priya S. Antipyretic activity of ethanol and aqueous extract of root of Asparagus racemosus in yeast induced pyrexia. Asian J Pharm Clin Res. 2013;6(3): 190-193.

[7] Hossain E, Mandal SC, Gupta JK. Phytochemical Screening and In-vivo AntipyreticActivity of the Methanol LeafExtract of Bombax Malabaricum DC (Bombacaceae). Trop J Pharm Res. February 2011; 10(1): 55.

[8] Bijekar SR, Gayatri MC. Phytochemical profile of Codiaeum variegatum (L.) Bl. International Journal of Pharmacology and Pharmaceutical Sciences. 2014; 2(3): 22-31.

[9] Basak M, Dey BK. Phytochemical and Antipyretic Potential of Ethanolic Leaf Extract of Heliotropium indicum L. Journal of Applied Pharmaceutical Research. 2016; 4(2): 06 - 10.

[10] Sasmal S, Majumdar S, Gupta M, Mukherjee PK. Pharmacognostical, phytochemical and pharmacological evaluation for the antipyretic effect of the seeds of Saraca asoca Roxb. Asian Pacific Journal of Tropical Biomedicine. 2012;2(10):782-786.

[11] Azam MG, Noman MS, Al-Amin MM. Phytochemical screening and antipyretic effect of Curcuma zedoaria Rosc. (Zingiberaceae) rhizome. Journal of Pharmaceutical Research International. 2014;4(5): 569-575.

[12] Gaichu DM, Mawia AM, Gitonga GM, Ngugi MP, Mburu DN. Phytochemical screening and antipyretic activities of dichloromethane-methanolic leaf and stem bark extracts of Ximenia americana in rat models. J Herbmed Pharmacol. 2017; 6(3): 107-113.

[13] Aronoff DM, Neilson EG. Antipyretics: mechanisms of action and clinical use in fever suppression. The American Journal of Medicine. 2001;111(4): 304-315.

[14] Tijjani MA, Mohammed GT, Tayib YA, Adamu TB, Abdulrahman FI. Phytochemical analysis, analgesic and antipyretic properties of ethanolic leaf extract of Vernonia amygdalina Del. J Herbmed Pharmacol. 2017;6(3):9599.

[15] Simmons DL, Wagner D, Westover K. Nonsteroidal Anti-Inflammatory Drugs, Acetaminophen, Cyclooxygenase 2, and Fever. Clinical Infectious Diseases. 2000; 31(Suppl 5): S211-8. 